\title{
EVALUATION OF PULP BROWNING IN MINIMALLY PROCESSED 'ROYAL GALA' APPLE TREATED WITH ERYTHORBIC ACID
}

\author{
Jardel Araujo Ribeiro" $^{*}$, Mauricio Seifert ${ }^{1}$, Rufino Fernando Flores Cantillano ${ }^{2}$, Gabriel \\ Dalmazo $^{1}$, Leonardo Nora ${ }^{1}$ \\ ${ }^{1}$ Programa de Pós-Graduação em Ciência e Tecnologia de Alimentos, Universidade Federal de Pelotas, \\ Campus Capão do Leão, s/n, 96010-900 - Caixa Postal 354 - Pelotas - RS, Brasil \\ ${ }^{2}$ Embrapa Clima Temperado, Rodovia BR 392, km 78, $9^{\circ}$ Distrito - Monte Bonito, RS, 96010-971, Brasil \\ *jardelaraujoribeiro@gmail.com
}

\begin{tabular}{|c|c|}
\hline Article history: & \multirow{17}{*}{$\begin{array}{l}\text { ABSTRACT } \\
\text { The production and marketing of minimally processed (MP) apple is } \\
\text { limited by the rapid and intense browning of the pulp. The application of } \\
\text { antioxidants is the main alternative to overcome this problem, but with } \\
\text { limited results, mainly due to the lack of information about the most } \\
\text { adequate concentration of antioxidant for a specific fruit under certain } \\
\text { storage conditions, such as type of packaging, temperature, humidity and } \\
\text { storage time. Therefore, the objective of this study was to evaluate the } \\
\text { effect of different concentrations of sodium erythorbate on color, weight } \\
\text { loss, total soluble solids (TSS), total acidity (TA), ratio (TSS / TA), total } \\
\text { phenols, antioxidant activity, and enzymatic activity (peroxidase and } \\
\text { polyphenoloxidase) in 'Royal Gala' apple MP during refrigerated storage. } \\
\text { Each fruit was cut in four wedge shape pieces of similar size, and } \\
\text { immediately immersed ( } 1.0 \text { min) in the antioxidant solutions: (a) distilled } \\
\text { water - negative control; (b) L-cysteine chloride } 0.6 \% \text { [m. } \mathrm{v}^{-1} \text { - positive } \\
\text { control; (c) erythorbic acid } 1.0 \% \text { [m. } \mathrm{v}^{-1} \text { ]; (d) erythorbic acid } 2.0 \% \text { [m. } \mathrm{v}^{-1} \text { ] } \\
\text { and (e) erythorbic acid } 3.0 \% \text { [m. } \mathrm{v}^{-1} \text { ]. The activity of the enzymes } \\
\text { peroxidase and polyphenoloxidase increased throughout the storage, } \\
\text { however, in the apples where the antioxidants L-cysteine }(0.6 \%) \text { and } \\
\text { erythorbic acid (1\%, } 2 \% \text { and } 3 \% \text { ) were applied the enzymatic activity was } \\
\text { lower than the control. The } 3 \% \text { erythorbic acid, in addition to satisfactorily } \\
\text { preserving the color, preserved the phenolic compounds and the } \\
\text { antioxidant activity during the nine days of refrigerated storage. }\end{array}$} \\
\hline Received: & \\
\hline 13 August 2018 & \\
\hline Accepted: & \\
\hline 20 February 2019 & \\
\hline Keywords: & \\
\hline Enzymatic browning; & \\
\hline Antioxidant activity; & \\
\hline Polyphenoloxidase. & \\
\hline & \\
\hline & \\
\hline & \\
\hline & \\
\hline & \\
\hline & \\
\hline & \\
\hline & \\
\hline
\end{tabular}

\section{Introduction}

The demand for minimally processed (MP) fruits and vegetables is growing in the food market. However, consumers look for fresh products with organoleptic characteristics close to in natura equivalents (Tappi et al., 2017). The preparation of MP products consists of a series of steps, such as sanitizing, cutting, packaging, storage, marketing, among others (Segura-Ponce et al., 2018). These steps decrease the products shelf life (Putnik et al., 2017) and cause enzymatic browning (EB), especially in apples (Malus domestica Borkh). Thus, the control of EB is of great importance, as it occurs in many fruits and vegetables and negatively affect attributes of color, taste and nutritional value (Holderbaum et al., 2010, Ioannou and Ghoul 2013). Dogan and Dogan (2004) observed that colour changes 
in apple pulp occur due to the high concentration of phenolic compounds in this fruit. This occurs because cutting and other mechanical damage allow oxygen penetration into tissues, resulting in rapid darkening by the oxidation of phenolic compounds. In this process, quinones are polymerized with other quinones or with phenolic compounds, resulting in the appearance of brown pigments (Kim et al., 2017). The phenolic substrates involved in the darkening reaction (e.g. 5-caffeoylquinic acid) are separated from polyphenoloxidase (PPO) enzyme inside intact organelles (vacuoles and plastids, respectively), thus inhibiting the darkening reaction. The cutting, or other mechanical damage during minimal processing, allow enzymes and substrates to react, causing tissue browning. Genetically modified apple cultivars, resistant to enzymatic darkening, have already been successfully obtained (Espley et al., 2013). However, although it is already in the commercialization phase, these cultivars remain little diffused due to their compatibility with different edaphoclimatic conditions and also the consumer resistance to consuming genetically modified products. In this context, one of the alternatives to inhibit enzymatic darkening in MP apples is the use of antioxidant agents. A commonly used agent is L-cysteine; this amino acid contains a thiol group with reduction properties (Richard-Forget et al., 1992). Several studies have demonstrated the efficiency of L-cysteine in the inhibition of pulp darkening of MP products such as 'Red Delicious' apples (Eissa et al., 2006), Fuji apples (Moreno et al., 2016), 'Stylist' lettuce (Bernardo et al., 2015) and Lychia (Ali et al., 2016). Similarly, the antioxidant erythorbic acid (D-isoascorbic acid) (Kall and Andersen 1999, Sun et al., 2013) is a stereoisomer of ascorbic acid but without the activity of vitamin $\mathrm{C}$. This antioxidant has the same properties of its stereoisomer but five times cheaper (Pineli et al., 2005, Martin-Belloso and Fortuny 2010). The use of EA as an antibrowning agent was evaluated in MP 'Ágata' potatoes (Pineli et al., 2005), canned apple and beer (Andersen 1999). In addition, EA is considered a safe food antioxidant in the European Union and the US, when used according to its legislation (Sun et al., 2013, EFSA 2016). Despite the proven antioxidant properties, there are few reports in the literature evaluating the use of EA as a darkening inhibitor in MP apples.

In this context, the objective of this study was to test different concentrations of EA for the maintenance of physicochemical attributes in MP 'Royal Gala' apples stored in refrigerated environment for up to nine days.

\section{Materials and methods}

\subsection{Apples and maturity indices}

Samples of apple (Malus domestica Borkh 'Royal Gala') were harvested in the year of 2014, from a commercial orchard located in the municipality of Vacaria, Rio Grande do Sul, Brazil (28 30' 44" S, 50 56 $02 " \mathrm{O})$. Apples were harvested considering their commercial mature stage, based on the average starch content (4.80) measured according to Travers et al., (2002), on a scale from 1 (one) to 10 (ten), where 1 and 10 correspond to the maximum and minimum content of starch, respectively; pulp firmness $(12.84 \mathrm{~N})$; concentration of total soluble solids (12.03 ${ }^{\circ}$ Brix $)$ and titratable acidity $(0.22 \mathrm{~g}$ of malic acid $100 \mathrm{~g}^{-1} \mathrm{FW}$ ), measured according to the methods described below. Samples were selected according to size, the absence of visible mechanical damage and rot. Fruits were temporarily stored (few weeks) at 
$1.0{ }^{\circ} \mathrm{C}$, relative humidity of $90.0 \% \pm 5.0 \%$, and finally used in the present study at the Postharvest Physiology Laboratory, Food Center, Embrapa Clima Temperado.

\subsection{Sanitization, cutting and dipping}

Fruits were washed and sanitized by dipping into a sodium hypochlorite solution (100 ppm, $\mathrm{pH} 6.5$, at $6.5^{\circ} \mathrm{C} \pm 1.5^{\circ} \mathrm{C}$ ), for $10 \mathrm{~min}$. Each fruit was cut in four wedge shape pieces of similar size; the central core and seeds were discarded and the fruit epidermis was preserved. After cutting, the apple pieces were dipped for $1.0 \mathrm{~min}$ in the following liquids: (a) distilled water control (CT), (b) L-cysteine chloride $0.6 \%$ $\left[\mathrm{m} \mathrm{v}^{-1}\right]$ positive control (LC), (c) erythorbic acid $1.0 \% \quad\left[\mathrm{~m}^{-1} \mathrm{v}^{-1}\right] \quad(\mathrm{EA} \quad 1.0 \%), \quad$ (d) erythorbic acid $2.0 \% \quad\left[\mathrm{~m}^{-1} \mathrm{v}^{-1}\right]($ EA $2.0 \%)$ and (e) erythorbic acid $3.0 \%\left[\mathrm{~m} . \mathrm{v}^{-1}\right](\mathrm{EA}$ $3.0 \%)$. After the immersion, the apple pieces were drained for $5 \mathrm{~min}$, placed in trays of expanded polystyrene, wrapped with PVC film ( $9 \mu \mathrm{m}$ thick) and stored for different periods $(0 \mathrm{~d}, 3 \mathrm{~d}, 6 \mathrm{~d}, 9 \mathrm{~d})$ at $4.0^{\circ} \mathrm{C}$ $\pm 1.0{ }^{\circ} \mathrm{C}$ and relative humidity of $90.0 \%$ $\pm 5.0 \%$, for simulation of shelf-life.

\subsection{Physicochemical analysis}

2.3.1. Color measurement: measured on the equatorial region of the wedge-shape pieces of apple, on the pulp, using a Minolta CR400 colorimeter with a CIE L*a*b* reading system, proposed by the Commission Internationale de I'Eclairage (CIE). These parameters were used to calculate the browning index (BI) according Palou et al., (1999).

2.3.2. Mass loss: measured according to Pereira et al. (2006) with the formula $M L(\%)=(M i-M f) / M i \times 100$, where $M i$ and $M f$ correspond to the apple pieces initial mass and final mass, respectively;
2.3.3. Pulp firmness: measured according to Melo et al., (2009) using a Texture Analyser (TA XT plus 40855, Stable Microsystems, England) with a $2 \mathrm{~mm}$ diameter probe, penetration depth of $5 \mathrm{~mm}$, pre-test velocity of $1.0 \mathrm{~mm} \mathrm{~s}^{-1} ; 2.0 \mathrm{~mm} \mathrm{~s}^{-1}$ test; post-test of $10.0 \mathrm{~mm} \mathrm{~s}^{-1}$ and force of $5 \mathrm{~kg}$. The readings were performed in the middle portion of the pieces and the results were expressed in Newton $(\mathrm{N})$.

2.3.4. Soluble solids: determined by using an Atago refractometer (ATAGO, model $\left.\mathrm{PAL}^{-1}\right)$, with results expressed as ${ }^{\circ} \mathrm{Brix}$.

2.3.5. Titratable acidity: obtained by titration of $0.1 \mathrm{M} \mathrm{NaOH}$ solution into 100 $\mathrm{mL}$ sample solution $(10 \mathrm{~mL}$ mashed pulp $+90 \mathrm{~mL}$ distilled $\mathrm{H}_{2} \mathrm{O}$ ) using a digital burette $\left(\right.$ Brand $\left.^{\circledR}\right)$ until $\mathrm{pH}$ stabilization at 8.1; the results were expressed in $\mathrm{mg}$ of malic acid equivalents (MAE) per $100 \mathrm{~g}$ of pulp (FW).

\subsubsection{Antioxidant activity (DPPH):} evaluated using the method described by Brand-Williams et al., (2005), with some modifications. First, $10 \mathrm{~mL}$ of methanol was added to $2.5 \mathrm{~g}$ of fresh apple and homogenized for $1.0 \mathrm{~min}$ (ultra-turrax homogenizer, IKA). Extracts were centrifuged at $4000 \mathrm{rpm}, 30 \mathrm{~min}, 1.0^{\circ} \mathrm{C}$ (Eppendorf - Centrifuge 5810R - Rotor F-45-30-11). The supernatant was collected and stored at $-80{ }^{\circ} \mathrm{C}$ until analysis. Apple extract $(100 \mu \mathrm{L})$ was added to $3900 \mu \mathrm{L}$ $\mathrm{DPPH}^{\circ}$ solution (in methanol), and the reaction mixture was kept in the dark for $24 \mathrm{~h}$. After this period, the absorbance was spectrophotometrically read at $515 \mathrm{~nm}$. The results are expressed as $\mathrm{mg}$ of Trolox equivalent per $100 \mathrm{~g}$ of $\mathrm{FW}$.

2.3.7. Total phenolic compounds: measured according to the Folin-Ciocalteu method adapted from Swain and Hillis (1959). 
Briefly, $250 \mu \mathrm{L}$ aliquot of the extracts (the same used for $\mathrm{DPPH}^{\circ}$ analysis) was combined with $250 \mu \mathrm{L}$ of $0.25 \mathrm{M}$ FolinCiocalteu reagent and $4000 \mu \mathrm{L}$ ultrapure water. After $3 \mathrm{~min}$ of reaction, $500 \mu \mathrm{L}$ of $0.5 \mathrm{M} \quad \mathrm{Na}_{2} \mathrm{CO}_{3}$ was added, following incubation for $2 \mathrm{~h}$ at room temperature and absorbance reading at $725 \mathrm{~nm}$. The results were expressed as grams of chlorogenic acid equivalents (CAE) per $100 \mathrm{~g}$ of $\mathrm{FW}$. A chlorogenic acid standard curve (0.0 $\mathrm{mg} \mathrm{mL}^{-1}$ to $0.5 \mathrm{mg} \mathrm{mL}^{-1}$ ) was used.

\subsubsection{Polyphenoloxidase enzyme (PPO)} activity: determined according to the adapted methodology described by Cano et al., (1997), based on the increase of the absorbance $(420 \mathrm{~nm})$ rate at $25{ }^{\circ} \mathrm{C}$. Apple extracts were obtained as follows: $10 \mathrm{~mL}$ of phosphate buffer $(0.2 \mathrm{M}, \mathrm{pH} 7)$, containing $0.2 \mathrm{~g}$ of polyvinylpyrrolidone (PVP), was added to $5 \mathrm{~g}$ of apple and homogenized for 1 min (ultra-turrax homogenizer, IKA), filtered and centrifuged at $16000 \mathrm{~g}$. An aliquot of $0.1 \mathrm{~mL}$ of supernatant was then mixed with $2.9 \mathrm{~mL}$ of catechol $(0.11 \mathrm{M}$ in phosphate buffer $0.5 \mathrm{M}, \mathrm{pH}$ 7.0). The enzymatic activity was spectrophotometrically monitored at $420 \mathrm{~nm}$ for 3 minutes. The results are expressed as $\Delta \mathrm{A}_{420} \mathrm{~min}^{-1} \mathrm{~g}^{-1}$.

\subsubsection{Peroxidase enzyme (POD) activity:} determined according to the adapted methodology described by Cano et al., (1997), based on the increase of absorbance $(485 \mathrm{~nm})$ rate, at $25^{\circ} \mathrm{C}$, using the same extract obtained for polyphenoloxidase analysis. An aliquot of $50 \mu \mathrm{L}$ of apple extract was mixed with $2.7 \mathrm{~mL}$ of phosphate buffer $(0.05 \mathrm{M}, \mathrm{pH} 7.0), 0.1 \mu \mathrm{L}$ of hydrogen peroxide $\left(1.5 \%, \mathrm{v} \mathrm{v}^{-1}\right)$ and $200 \mu \mathrm{L}$ of guaiacol. The enzymatic activity was calculated based on the increase of absorbance at $485 \mathrm{~nm}$ as a function of time
(3 min). The results are expressed as $\Delta \mathrm{A}_{485}$ $\min ^{-1} \mathrm{~g}^{-1}$.

2.3.10. Statistical analysis: The experimental design was completely randomized in a factorial scheme with three biological replicates and three analytical replicates. Treatment factors were the storage time $(0 \mathrm{~d}, 3 \mathrm{~d}, 6 \mathrm{~d}$ and $9 \mathrm{~d})$ and the liquids for dipping the apple pieces: distilled water; $0.6 \%$ L-cysteine and erythorbic acid $(1 \%, 2 \%$ and $3 \%)$. Data normality was determined by Shapiro-Wilk test and variance homoscedasticity by the Hartley test. Later, the results were submitted to analysis of variance (One-Way ANOVA) $(p<0.05)$; when significative, the means were compared by the LSD test $(p<0.05)$.

\section{Results and discussions}

Enzymatic browning is the main cause of decline in quality and shelf life of minimally processed apples. Therefore, when evaluating the color parameters, there were significant $(\mathrm{p}<0.05)$ differences in the variables $\mathrm{L}^{*}, \mathrm{a} *, \mathrm{~b} *$ and darkening index. In relation to the $\mathrm{L} *$ coordinate (Figure 1a), all treatments with antioxidants, LC and EA $(1 \%, 2 \%$ and $3 \%)$, remained stable and higher than CT during storage. After $9 \mathrm{~d}$, EA $1 \%$ presented a small decrease and CT a small increase in $\mathrm{L}^{*}$ value, but without statistical differences. These results were different from those obtained by Vilas-Boas et al., (2015) when applying antioxidants to MP 'Williams' pears. Regardless of the antioxidant used, these authors observed a decrease in the $\mathrm{L}^{*}$ value along the refrigerated storage. The inactivation of POD and PPO enzymes by erythorbic acid acidification of pulp surface may have contributed to the maintenance of luminosity during storage. In addition, Qi et al., (2011) reported that storage at low temperature contributes to delay the loss of luminosity in MP apples. 
Regarding $\mathrm{a}^{*}$ coordinate (Figure 1b), LC and EA (1\%, $2 \%$ and $3 \%)$ also provided a satisfactory control in the darkening of the pulp until the third day of storage, since negative values of $a^{*}$ indicate pulp with a greenish-yellow coloration. From the sixth day on, only EA 3\% treatment was capable of maintaining the same coloration observed on the first day $(0 \mathrm{~d})$ of storage. In contrast, apples with reddish flesh (positive values of $a^{*}$ ) were observed under the treatments LC and EA
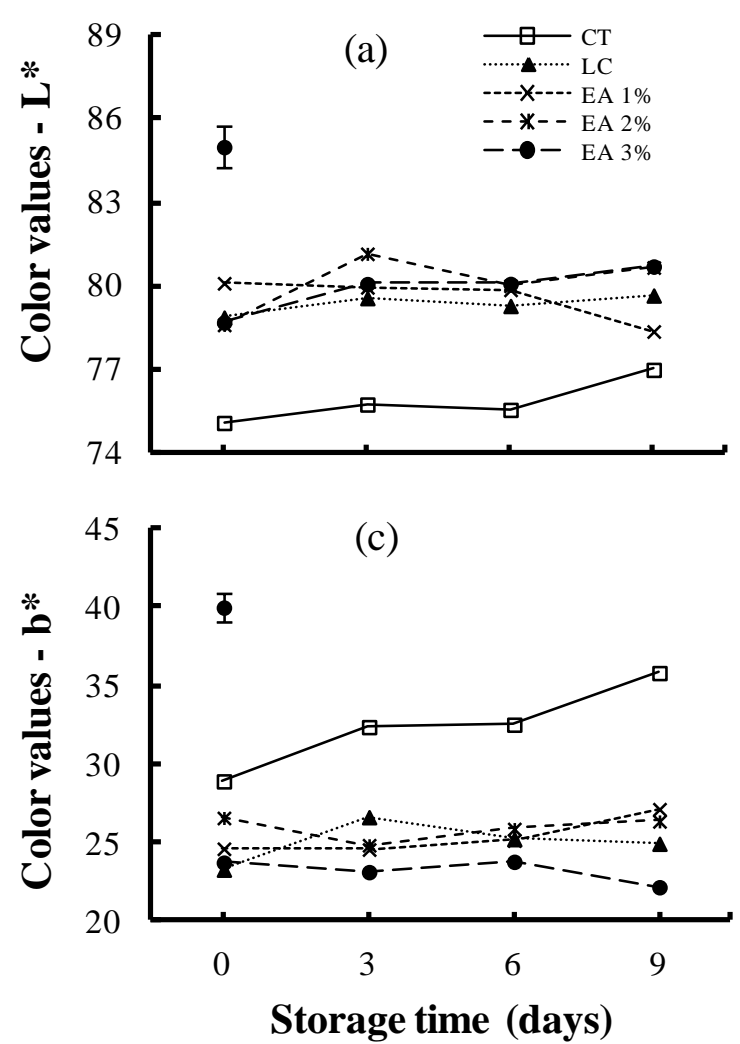

(1\% and $2 \%$ ), until the sixth day of storage. The reddish tint observed in apples treated with LC is possibly due to the regeneration of phenolic compounds; this occurs when low concentrations of this antioxidant are used (Martins et al., 2015). However, the satisfactory effect observed with EA $3 \%$ can be attributed to its strong reducing properties (Carocho et al., 2018), since this compound can react with oxygen and thus remove it from a closed system (Lee et al., 2012), avoiding the darkening of the pulp.
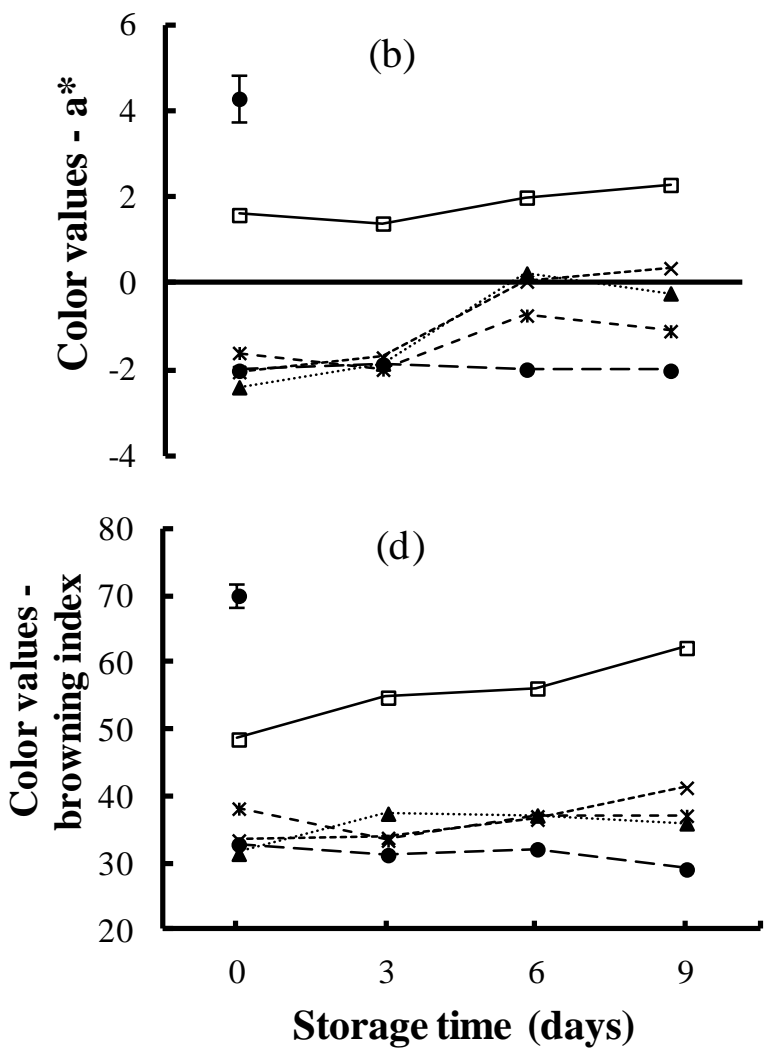

Figure 1. Color values, $\mathrm{L}^{*}(* \mathrm{LSD}=0.45), \mathrm{a}^{*}(* \mathrm{LSD}=0.27), \mathrm{b} *(* \mathrm{LSD}=0.78)$ and browning index $(* \mathrm{LSD}=1.67)$ measured in minimally processed 'Royal Gala' apples stored for $0 \mathrm{~d}, 3 \mathrm{~d}, 6 \mathrm{~d}$, and $9 \mathrm{~d}$ at $4.0{ }^{\circ} \mathrm{C} \pm 1.0{ }^{\circ} \mathrm{C}$, relative humidity of $90.0 \% \pm 5.0 \%$, after treatment with distilled water (CT) as negative control; L-cysteine chloride (LC) $0.6 \%\left(\mathrm{~m}^{-1} \mathrm{v}^{-1}\right)$ as a positive control; erythorbic acid (EA): EA $1 \%$ $\left(\mathrm{m} \cdot \mathrm{v}^{-1}\right)$, EA 2\% $\left(\mathrm{m} \cdot \mathrm{v}^{-1}\right)$ and EA 3\% $\left(\mathrm{m} \cdot \mathrm{v}^{-1}\right)$. *Vertical bars indicate the Least Significant Difference (LSD) at $\mathrm{p} \leq 0.05$.

Regarding the $b^{*}$ coordinate (Figure 1.c), although all antioxidants prevented pulp darkening, the EA $3 \%$ treatment resulted in a lighter pulp throughout the storage period. The process of oxidative staining is triggered by the membrane 
rupture inside cells (Toivonen 2004), which results in the mixture of substrates (polyphenols) with PPO enzyme (Cortellino et al., 2015). In the presence of oxygen, PPO catalyse the monophenols hydroxylation into diphenols and subsequently the oxidation of diphenols in quinones (Cortellino et al., 2015). The former reaction is relatively slow and results in colorless products; the latter is relatively rapid and results in colored quinones. Subsequent reactions that occur after quinones production lead to the melanin accumulation, a brown pigment that gives the oxidized MP products their characteristic color (Cortellino et al., 2015). Hence, $b^{*}$ values indicate a satisfactory action of the tested antioxidants, with emphasis on the EA $3 \%$. This result is similar to that observed by Pizato et al., (2013) when working with protein isolates on 'Gala' apples.

As for the browning index (Figure 1d), the different EA concentrations (1\%, $2 \%$ and $3 \%$ ) and LC maintained pulp darkening lower than CT during the evaluation period. The EA $3 \%$ kept the color of MP apples very close to that observed on the first day of storage (Figure 2), being the best treatment. It should be noted that the more intense yellow observed near the seed cavity (endocarp), in apples treated with EA 3\%, does not indicate ineffectiveness of this antioxidant, since this region is naturally more yellowish than the fleshy pulp (mesocarp).The satisfactory result obtained with EA 3\% is important because according to Altisent et al., (2014), the maintenance of MP fruit color indicates freshness and quality. The darkening inhibition process triggered by L-cysteine in apples pulp occurs through conjugation with $o$-quinones to form colorless compounds; another mechanism is the reduction of $o$-quinones to their phenolic compound precursors (Koblitz 2000). According to RichardForget et al., 1992, the compounds resulting from cysteine and $o$-quinones conjugation may act as competitive inhibitors of PPO, being another mechanism of darkening inhibition. However, when there is a quinone excess and all of the L-cysteine has been consumed, the former can react with the cysteine-quinone addition compounds, giving rise to violet pigments. This explains the slightly browning observed at the end of the storage in apples treated with LC $0.6 \%$. In addition, LC contains sulphur in its constitution, giving rise to volatile sulphur compounds during its metabolization; this alters the taste and characteristic odour of the products treated with this antioxidant. On the other hand, the EA provides color maintenance; without compromising the taste, aroma and nutritional quality in MP products (Salata et al., 2014). Because of that, there are advantages in its use in comparison to $\mathrm{LC}$, in addition to its low cost. According to Mishra et al., (2012), the EA prevents the darkening process by inhibiting the PPO enzyme and reducing quinone intermediates back to the diphenols (Mishra et al., 2012). Rojas-Grau et al., (2008), when working with ascorbic acid (AA), an ester of erythorbic acid, reported that although several authors have demonstrated the efficiency of AA in the control of enzymatic darkening, its efficacy is lower than that of L-cysteine. According to the authors, when AA is completely oxidized to dehydroascorbic acid, the quinones may again accumulate and cause browning. In view of this, it is assumed that the good results obtained with EA $3 \%$ are due to the higher concentration of this salt, retarding its oxidation and thus preventing pulp and bundle sheath darkening in MP apples. 


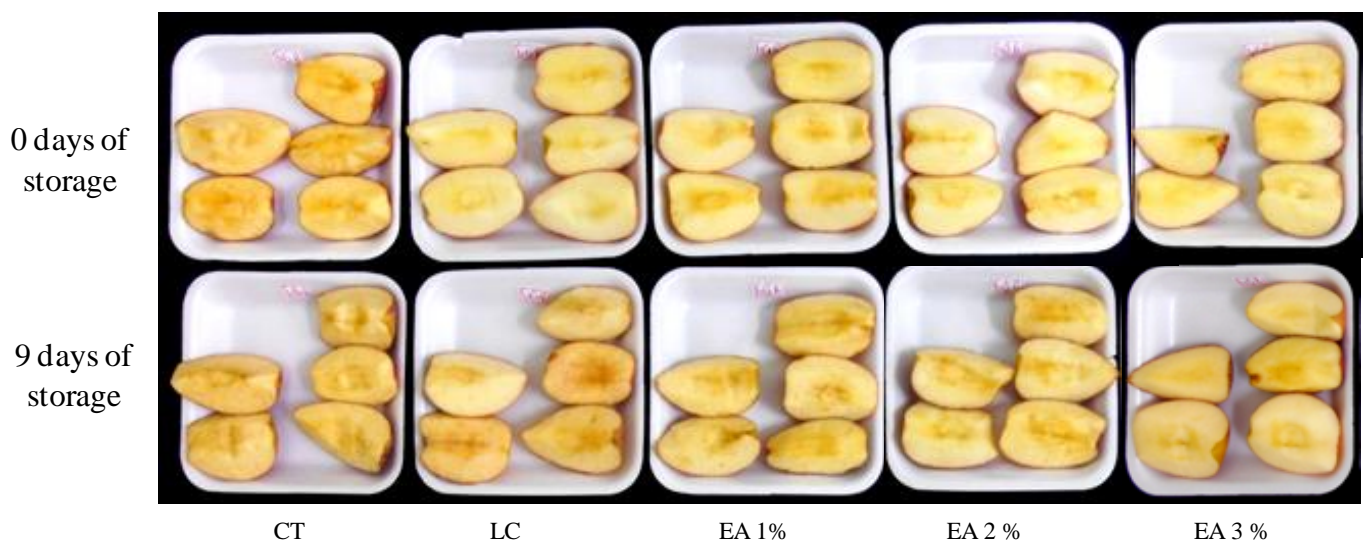

Figure 2. Pulp darkening of minimally processed apples, treated with distilled water, as negative control treatment (CT); L-cysteine chloride (LC) $0.6 \%\left(\mathrm{~m}^{-1} \mathrm{v}^{-1}\right)$, as a positive control; erythorbic acid (EA): EA $1 \%\left(\mathrm{~m} \cdot \mathrm{v}^{-1}\right)$, EA $2 \%\left(\mathrm{~m} \cdot \mathrm{v}^{-1}\right)$ and EA $3 \%\left(\mathrm{~m} \cdot \mathrm{v}^{-1}\right)$; stored for $0 \mathrm{~d}, 3 \mathrm{~d}, 6 \mathrm{~d}$, and $9 \mathrm{~d}$ at $4.0^{\circ} \mathrm{C} \pm 1.0^{\circ} \mathrm{C}$, and relative humidity of $90.0 \% \pm 5.0 \%$.

The ratio (total soluble solids / titratable acidity) is commonly used to evaluate fruit quality. A change in the ratio might affect how the apple taste (Piagentini and Pirovani 2017). This relationship (Figure 3a) had a small decrease in all treatments until the sixth day of storage, with a subsequent increase until the ninth day of storage. These changes can be explained by the metabolism of organic acids in the respiratory pathways and subsequent conversion into non-acidic molecules (Pech et al. 2008). Total soluble solids can also accumulate by protopectin hydrolysis into soluble pectin or by starch hydrolysis into glucose and fructose (Barnes and Anderson 2018; Liu et al. 2018).
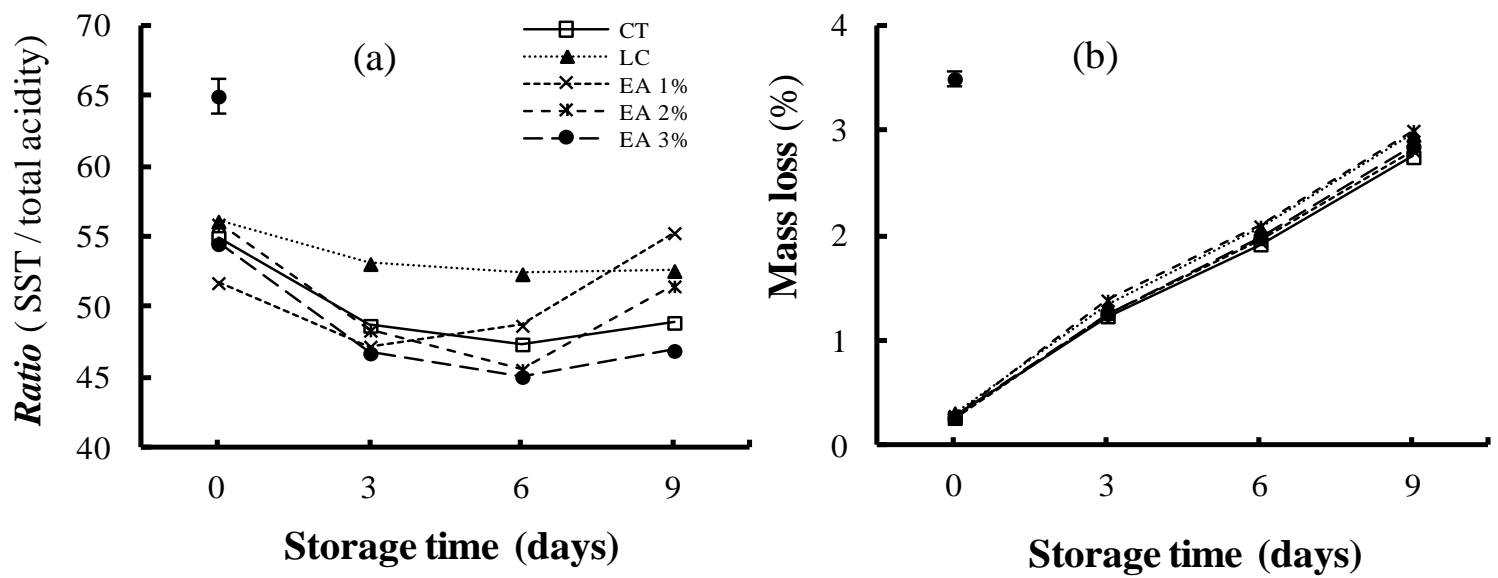

Figure 3. Ratio ( $\left.{ }^{*} \mathrm{LSD}=1.21\right)$ and mass loss $(* \mathrm{LSD}=0.067)$; measured in minimally processed 'Royal Gala' apples stored for $0 \mathrm{~d}, 3 \mathrm{~d}, 6 \mathrm{~d}$, and $9 \mathrm{~d}$ at $4.0{ }^{\circ} \mathrm{C} \pm 1.0^{\circ} \mathrm{C}$, relative humidity of $90.0 \% \pm 5.0 \%$, after treatment with distilled water as a negative control treatment (CT); L-cysteine chloride (LC) $0.6 \%$ $\left(\mathrm{m} \cdot \mathrm{v}^{-1}\right)$ as a positive control; and erythorbic acid (EA): EA $1 \%\left(\mathrm{~m} \cdot \mathrm{v}^{-1}\right)$, EA $2 \%\left(\mathrm{~m} \cdot \mathrm{v}^{-1}\right)$ and EA 3\% $\left(\mathrm{m} \cdot \mathrm{v}^{-1}\right)$. $*$ Vertical bars indicate the Least Significant Difference (LSD) at $\mathrm{p} \leq 0.05$. 
The mass loss, a limiting factor in the shelf life of MP fruits and vegetables, increased during storage; with a mean mass loss (Figure $3 \mathrm{~b}$ ) of $2.6 \%$ at the end of the storage period. This loss of mass was 5 times lower than that observed by Sumonsiri (2017) when working with ascorbic acid and nisin on 'Fuji' MP apples. The gradual mass loss throughout storage is due to pulp exposure to the atmosphere, potentiating the loss of water (Pajak et al., 2017). Despite the significant differences observed between treatments, the mass loss was minimal, not compromising the final quality of the product. The pulp firmness (data not shown) did not differ between treatments and along the storage period, with a mean value of $2.5 \mathrm{~N}$.

Apples contain large amounts of endogenous phenolic compounds with antioxidant properties (Kim et al., 2017), as well as ascorbic acid (up to $0.25 \mathrm{~g} \mathrm{~kg}^{-1}$ ). However, the antioxidant loading could be complemented by the immersion of MP fruit in solutions containing exogenous antioxidants (Aguayo et al., 2010). This process aims to interfere in oxidation reactions after MP and preserve endogenous phenolic compounds and ascorbic acid (Aguayo et al., 2010). When evaluating the concentrations of phenolic compounds in apples treated with antioxidant solutions (Figure 4a), it was observed that the EA $3 \%$ maintained phenolic compounds concentrations constant during the nine days. In addition, it promoted the increase of these bioactive compounds throughout storage. The other treatments (LC, EA $1 \%$ and EA $2 \%$ ), although resulting a lower amount of phenolics, remained within the values reported in the literature (50 mg.100 g $\mathrm{g}^{-1} \mathrm{FW}$ to $380 \mathrm{mg} .100 \mathrm{~g}^{-1} \mathrm{FW}$ ) (Ceymann et al., 2012). The application of EA $3 \%$ maintained the concentrations of phenolic compounds. It occurs because EA, together with its stereoisomers, limits the production of $o$-quinones (Grant-Preece et al., 2013) by eliminating oxygen from the tissue before it reacts with the phenolic compounds (Clark et al., 2009, Bradshaw et al., 2011). In the absence of the antioxidant, PPO catalyses the phenolic compounds oxidation leading to the formation of undesirable pigments in the apple pulp (Zorzella et al., 2003). Oxidation, in addition to causing browning, may also result in loss of nutritional quality and provide flavor modifications. According to Son et al., (2001), the brown color intensity resulting from the PPO activity depends on the type of phenolic compounds involved.

The antioxidant activity was quantified based on the free radical scavenging activity (DPPH) (Figure 4b). The observed behavior for antioxidant activity was similar to that observed for total phenols (Figure 4a). EA $3 \%$ resulted in the highest antioxidant activity, with a tendency to increase throughout storage, corresponding to a significant increase in free radical sequestration, from $444.68 \mathrm{mg}$ Trolox.100 g $\mathrm{g}^{-1}$ FW (0 d) to $505.50 \mathrm{mg}$ Trolox.100 $\mathrm{g}^{-1} \mathrm{FW}(9 \mathrm{~d})$; an increase of $12 \%$. Aguayo et al., (2010) when working with the addition of antioxidants in 'Mariri Red' apples reported that to maintain a higher antioxidant activity than in the control treatment, a treatment with at least $6 \%$ of calcium ascorbate was necessary. In the present study, EA $3 \%$ maintained the antioxidant activity higher than in the TC as follows: $12.96 \% \quad(0 \mathrm{~d}), 14.11 \% \quad(3 \mathrm{~d})$, $21.73 \%(6 \mathrm{~d})$ and $28.12 \%(9 \mathrm{~d})$. The increase in antioxidant activity over time can be attributed to the preservation of polyphenols, as shown previously. EA has antioxidant action due to its reducing 
properties (Watanabe et al., 2014), acting in similar manner to AA (Clark et al., 2009). EA is considered safe for human consumption, low cost, well accepted by consumers and capable to increase the vitamin C content (Loan; Manzano, 1993), even though it presents only $5 \%$ of the AA vitamin activity. As for LC, its ability to preserve antioxidant activity in apples is attributed to its ability to sequester free radicals due to the presence of a thiol group (Altunkaya and Gökmen, 2008).
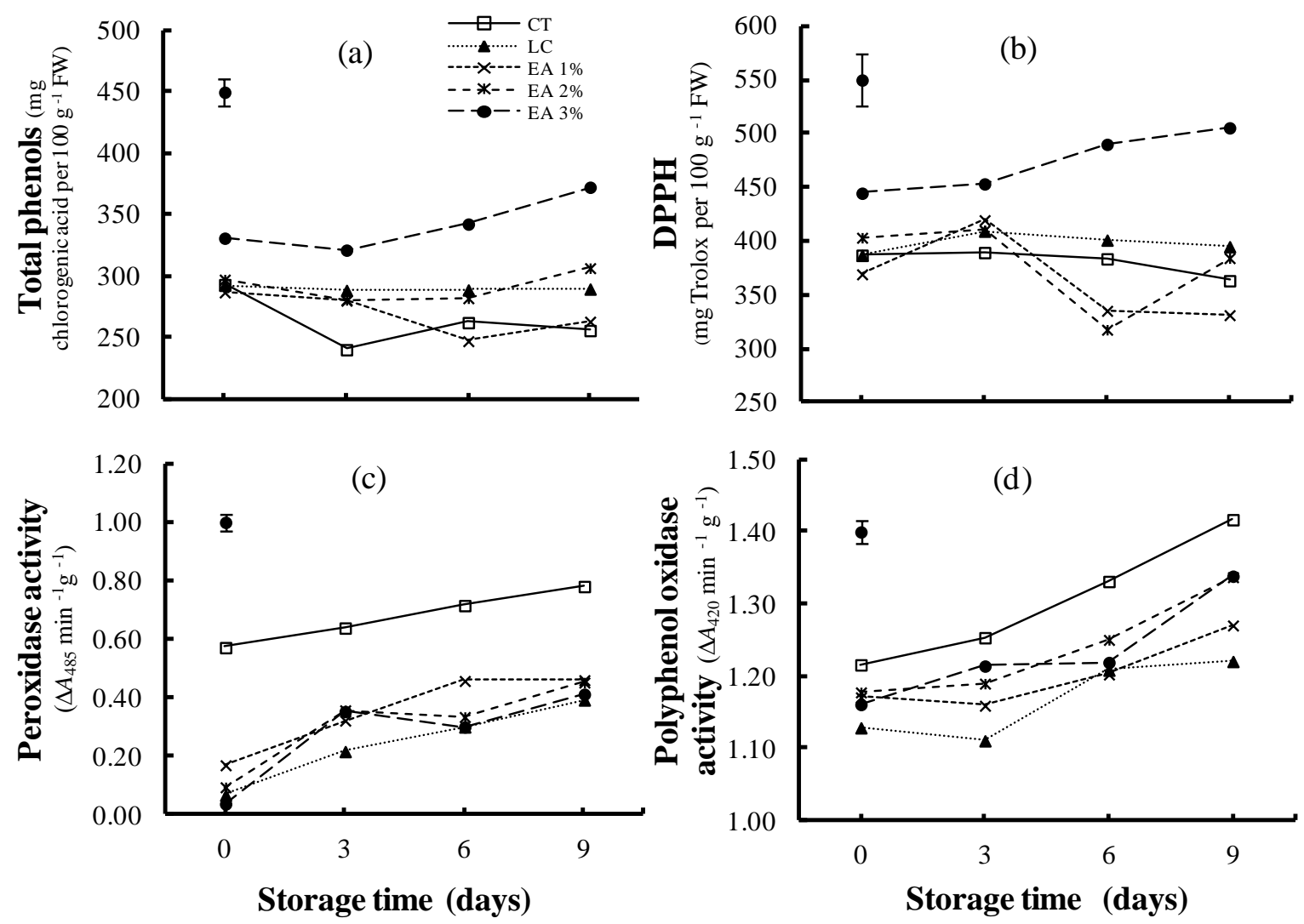

Figure 4. Total phenols $(* \operatorname{LSD}=11.37)$, DPPH $(* \operatorname{LSD}=24.20)$, peroxidase activity $(*$ LSD $=0.026)$ and polyphenoloxidase activity ( $\left.{ }^{*} \mathrm{LSD}=0.014\right)$ in minimally processed 'Royal Gala' apples stored for $0 \mathrm{~d}, 3 \mathrm{~d}, 6 \mathrm{~d}$, and $9 \mathrm{~d}$ at $4.0{ }^{\circ} \mathrm{C} \pm 1.0^{\circ} \mathrm{C}$, relative humidity of $90.0 \% \pm 5.0 \%$, after treatment with distilled water as a negative control treatment (CT); L-cysteine chloride (LC) $0.6 \%\left(\mathrm{~m}^{\left.-\mathrm{v}^{-1}\right)}\right.$ as a positive control; and erythorbic acid (EA): EA $1 \%\left(\mathrm{~m} . \mathrm{v}^{-1}\right)$, EA $2 \%\left(\mathrm{~m} \cdot \mathrm{v}^{-1}\right)$ and EA $3 \%\left(\mathrm{~m} \cdot \mathrm{v}^{-1}\right)$. *Vertical bars indicate the Least Significant Difference (LSD) at $\mathrm{p} \leq 0.05$.

The control of PPO and POD activity after MP is important because these enzymes are involved in the darkening process; it occurs almost instantly after destruction of the cellular structure (Jang and Moon 2011). There was an increase in POD activity along the storage (Figure 4c), regardless of the application of antioxidants.
The remarkable difference was the lower activity of POD under LC and EA (1\%, $2 \%$ and $3 \%$ ) treatment in comparison to the activity under the CT. Considering that EA is an AA stereoisomer, the reduction in activity is in accordance with the results reported by Jang and Moon (2011), where the presence of AA effectively reduced POD 
activity in MP apples. The reduced POD activity in AA treated fruits could be the result of lower oxidative stress on the fruit surface, due to the antioxidant nature of the molecular AA; it could also be a result of the formation of the POD-hydrogen donor complex (Saba and Sogvar, 2016).

The results observed for PPO activity (Figure 4d) are similar to those of POD activity. There was an increase in the PPO activity for all the treatments during the nine days of storage. Although there were oscillations in the enzymatic activity in apples treated with the antioxidant solutions, the PPO activity of these treatments was lower than the activity observed under the CT. Similar results were observed by Mirshekari et al., (2017) when working with MP 'Berangan' bananas treated with calcium propionate and chitosan. Even without major differences in POD and PPO activity among antioxidant treatments, LC and EA (1\%, $2 \%$ and $3 \%$ ), the phenolic substrates were preserved as previously shown. This is an important result because one of the main reasons for the darkening of many fresh fruits and vegetables is the oxidation of phenolic substrates by PPO (Nguyen et al., 2003, Xing et al., 2010) and POD (Jang and Moon 2011). In addition to the antioxidant effect of LC and EA, the low $\mathrm{pH}$ of these solutions (2.22 and 1.62, respectively) may have contributed to the reduction of enzymatic activity. Tsouvaltzis and Brecht, (2017) when working with MP 'Russet Burbank' potatoes found that immersion of the MP tubers in $\mathrm{H}_{2} \mathrm{SO}_{4} \mathrm{pH} 2.39(<0.04 \%)$ reduced the PPO activity in comparison to the control treatment. According to these authors, this occurred because the optimum $\mathrm{pH}$ for the enzymatic activity (pH 5 to $\mathrm{pH} 7$ ) was altered.

\section{Conclusions}

The use of erythorbic acid $3 \%\left(\mathrm{~m} . \mathrm{v}^{-1}\right)$ efficiently controls enzymatic browning and preserves physicochemical characteristics of minimally processed 'Royal Gala' apples under refrigeration for up to nine days.

\section{References}

Aguayo, E., Requejo-Jackman, C., Stanley, R., Woolf, A. (2010). Effects of calcium ascorbate treatments and storage atmosphere on antioxidant activity and quality of fresh-cut apple slices. Postharvest Biology and Technology 57(1): 52-60.

Ali, S., Khan, A. S., Malik, A. U. (2016). Postharvest L-cysteine application delayed pericarp browning, suppressed lipid peroxidation and maintained antioxidative activities of litchi fruit. Postharvest Biology and Technology 121: 135-142.

Altisent, R., Plaza, L., Alegre, I., Vinas, I., Abadias, M. (2014). Comparative study of improved vs. traditional apple cultivars and their aptitude to be minimally processed as 'ready to eat' apple wedges. Lwt-Food Science and Technology 58(2): 541-549.

Altunkaya, A., Gökmen, V. (2008). Effect of various inhibitors on enzymatic browning, antioxidant activity and total phenol content of fresh lettuce (Lactuca sativa). Food Chemistry, 107(3), 11731179.

Andersen, F. A. (1999). Final Report on the Safety Assessment of Ascorbyl Palmitate, Ascorbyl Dipalmitate, Ascorbyl Stearate, Erythorbic Acid, and sodium Erythorbate. International Journal of Toxicology 18(3_suppl): 126.

Barnes, W. J., Anderson, C. T. (2018). Cytosolic invertases contribute to cellulose biosynthesis and influence carbon partitioning in seedlings of Arabidopsis thaliana. The Plant Journal. 
Bernardo, P., Imperatrice, C., Maddalena, V., Maria, C. (2015). Evaluation of L-Cysteine as Anti-Browning Agent in Fresh-Cut Lettuce Processing. Journal of Food Processing and Preservation 39(6): 985-993.

Bradshaw, M. P., Barril, C., Clark, A. C., Prenzler, P. D., Scollary, G. R. (2011). Ascorbic Acid: A Review of its Chemistry and Reactivity in Relation to a Wine Environment. Critical Reviews in Food Science and Nutrition 51(6): 479-498.

Brand-Williams, W., Cuvelier, M. E., Berset, C. (1995). Use of a free radical method to evaluate antioxidant activity. LWT - Food Science and Technology 28(1): 25-30.

Cano, M. P., de Ancos, B., Matallana, M. C., Cámara, M., Reglero, G., Tabera, J. (1997). Differences among Spanish and Latin-American banana cultivars: morphological, chemical and sensory characteristics. Food Chemistry 59(3): 411-419.

Carocho, M., Morales, P., Ferreira, I. C. F. R. (2018). Antioxidants: Reviewing the chemistry, food applications, legislation and role as preservatives. Trends in Food Science \& Technology 71: 107120.

Ceymann, M., Arrigoni, E., Schärer, H., Bozzi Nising, A., Hurrell, R. F. (2012). Identification of apples rich in healthpromoting flavan-3-ols and phenolic acids by measuring the polyphenol profile. Journal of Food Composition and Analysis 26(1): 128-135.

Clark, A. C., Vestner, J., Barril, C., Maury, C., Prenzler, P. D., Scollary, G. R. (2009). The Influence of Stereochemistry of Antioxidants and Flavanols on Oxidation Processes in a Model Wine System: Ascorbic Acid, Erythorbic Acid, (+)-Catechin and (-)Epicatechin. Journal of Agricultural and Food Chemistry 58(2): 1004-1011.
Cortellino, G., Gobbi, S., Bianchi, G., Rizzolo, A. (2015). Modified atmosphere packaging for shelf life extension of fresh-cut apples. Trends in Food Science \& Technology 46(2, Part B): 320-330.

Dogan, S., Dogan, M. (2004). Determination of kinetic properties of polyphenol oxidase from Thymus (Thymus longicaulis subsp. chaubardii var. chaubardii). Food Chemistry 88(1): 69-77.

EFSA (2016). Scientific Opinion on the re-evaluation of erythorbic acid (E 315) and sodium erythorbate (E 316) as food additives. EFSA Journal. 14: 4360.

Espley, R. V., Bovy, A., Bava, C., Jaeger, S. R., Tomes, S., Norling, C., ... \& Putterill, J. (2013). Analysis of genetically modified red-fleshed apples reveals effects on growth and consumer attributes. Plant biotechnology journal, 11(4), 408-419.

Eissa, H. A., Fadel, H. H. M., Ibrahim, G. E., Hassan, I. M., Elrashid, A. A. (2006). Thiol containing compounds as controlling agents of enzymatic browning in some apple products. Food Research International 39(8): 855-863.

Grant-Preece, P., Fang, H., Schmidtke, L. M., Clark, A. C. (2013). Sensorially important aldehyde production from amino acids in model wine systems: Impact of ascorbic acid, erythorbic acid, glutathione and sulphur dioxide. Food Chemistry 141(1): 304-312.

Holderbaum, D. F., Kon, T., Kudo, T., Guerra, M. P. (2010). Enzymatic Browning, Polyphenol Oxidase Activity, and Polyphenols in Four Apple Cultivars: Dynamics during Fruit Development. Hortscience 45(8): 11501154.

Ioannou, I., Ghoul, M. (2013). Prevention of enzymatic browning in fruit and vegetables. European Scientific Journal 9(30): 310-341. 
Jang, J.-H., Moon, K.-D. (2011). Inhibition of polyphenol oxidase and peroxidase activities on fresh-cut apple by simultaneous treatment of ultrasound and ascorbic acid. Food Chemistry 124(2): 444-449.

Kall, M. A., Andersen, C. (1999). Improved method for simultaneous determination of ascorbic acid and dehydroascorbic acid, isoascorbic acid and dehydroisoascorbic acid in food and biological samples. Journal of Chromatography B 730(1): 101-111.

Kim, A. N., Kim, H. J., Kerr, W. L., Choi, S. G. (2017). The effect of grinding at various vacuum levels on the color, phenolics, and antioxidant properties of apple. Food chemistry, 216: 234-242.

Koblitz, M. G. B. (2000). Bioquímica de alimentos: teoria e aplicações práticas. Grupo Gen-Guanabara Koogan

Lee, D. E., Park, K. M., Choi, S. J., Chang, P. S. (2012). Optimal production and structural characterization of erythorbyl laurate obtained through lipasecatalyzed esterification. Food Science and Biotechnology 21(4): 1209-1215.

Liu, H., Qian, M., Song, C., Li, J., Zhao, C., Li, G., Wang, A., Han, M. (2018). Down-Regulation of PpBGAL10 and PpBGAL16 Delays Fruit Softening in Peach by Reducing Polygalacturonase and Pectin Methylesterase Activity. Frontiers in plant science, 9.

Martin-Belloso, O., Fortuny, R. S. (2010). Advances in Fresh-Cut Fruits and Vegetables Processing. Boca Raton: CRC Press.

Martins, E. M. F., Ramos, A. M., Martins, M. L., de Oliveira, P. M., Stringheta, P. C. (2015). Minimally processed fruit salad enriched with Lactobacillus acidophilus: Viability of anti-browning compounds in the preservation of color. African Journal of Biotechnology 14(24): 2022-2027.

Melo, A. A. M., Vilas Boas, E. V. de B., Justo, C. F. 2009. Uso de aditivos químicos para a conservação póscolheita de Banana 'maçã' minimamente processada. Ciência e Agrotecnologia, Lavras 33(1): 228-236.

Mirshekari, A., Madani, B., Golding, J. B. (2017). Suitability of combination of calcium propionate and chitosan for preserving minimally processed banana quality. Journal of the Science of Food and Agriculture 97(11): 3706-3711.

Mishra, B. B., Gautam, S., Sharma, A. (2012). Purification and characterisation of polyphenol oxidase (PPO) from eggplant (Solanum melongena). Food Chemistry 134(4): 1855-1861.

Moreno, M. B., Cantillano, R. F. F., Rombaldi, C. V., Manica-Berto, R. (2016). Quality of minimally processed fuji apple under refrigerated storage and treatment with additives. Revista Brasileira de Fruticultura 38(4): e-532.

Nguyen, T. B. T., Ketsa, S., van Doorn, W. G. (2003). Relationship between browning and the activities of polyphenoloxidase and phenylalanine ammonia lyase in banana peel during low temperature storage. Postharvest Biology and Technology 30(2): 187193.

Pajak, P., Socha, R., Łakoma, P., Fortuna, T. (2017). Antioxidant properties of apple slices stored in starch-based films. International Journal of Food Properties, 20(5): 1117-1128.

Palou, E., Lopez-Malo, A., BarbosaCanovas, G. V., Welti-Chanes, J., Swanson, B. G. (1999). Polyphenoloxidase activity and color of blanched and high hydrostatic pressure treated banana puree. Journal of Food Science 64(1): 42-45.

Pech, J. C., Bouzayen, M., Latche, A. (2008). Climacteric fruit ripening: Ethylene-dependent and independent regulation of ripening pathways in melon fruit. Plant Science 175(1-2): $114-120$ 
Pereira, M. E. C., Silva, A. S., Bispo, A. S., Santos, D. B., Santos, S. B., Santos, V. J. (2006). Amadurecimento de mamão formosa com revestimento comestível à base de fécula de mandioca. Ciência $e$ Agrotecnologia 30(6): 1116-1119.

Piagentini, A. M., Pirovani, M. E. (2017). Total Phenolics Content, Antioxidant Capacity, Physicochemical Attributes, and Browning Susceptibility of Different Apple Cultivars for Minimal Processing. International Journal of Fruit Science 17(1): 102-116.

Pineli, L. L. O., Moretti, C. L., Almeida, G. C., Nascimento, A. B. G., Onuki, A. C. A. (2005). Associação de atmosfera modificada e antioxidantes reduz $\mathrm{o}$ escurecimento de batatas 'Ágata' minimamente processadas. Horticultura Brasileira 23(4): 993-999.

Pizato, S., Cortez-Vega, W. R., Da Costa, T. S., De Oliveira, L. M., Prentice, C. (2013). Improvement Quality and Shelf Life Assessment of Minimally Processed Apples by Use of Protein Coatings. Journal of Food Research 2(5): 24-33.

Putnik, P., Kovačević, D. B., Herceg, K., Roohinejad, S., Greiner, R., Bekhit, A. E. D. A., Levaj, B. (2017). Modelling the shelf-life of minimally-processed fresh-cut apples packaged in a modified atmosphere using food quality parameters. Food control, 81: 55-64.

Qi, H., Hu, W., Jiang, A., Tian, M., Li, Y. (2011). Extending shelf-life of Freshcut 'Fuji' apples with chitosan-coatings. Innovative Food Science \& Emerging Technologies 12(1): 62-66.

Richard-Forget, F. C., Goupy, P. M., Nicolas, J. J. (1992). Cysteine as an inhibitor of enzymatic browning: Kinetic-studies. Journal of Agricultural and Food Chemistry 40(11): 21082113.

Rojas-Grau, M. A., Soliva-Fortuny, R., Martin-Belloso, O. (2008). Effect of natural antibrowning agents on color and related enzymes in fresh-cut Fuji apples as an alternative to the use of ascorbic acid. Journal of Food Science 73(6): S267-S272.

Saba, M. K., Sogvar, O. B. (2016). Combination of carboxymethyl cellulose-based coatings with calcium and ascorbic acid impacts in browning and quality of fresh-cut apples. LwtFood Science and Technology 66: 165171.

Salata, A. C., Cardoso, A. I., Evangelista, R. M., Magro, F. O. (2014). Uso de ácido ascórbico e cloreto de cálcio na qualidade de repolho minimamente processado. Horticultura Brasileira 32: 391-397

Segura-Ponce, L. A., Reyes, J. E., Troncoso-Contreras, G., ValenzuelaTapia, G. (2018). Effect of Lowpressure Cold Plasma (LPCP) on the Wettability and the Inactivation of Escherichia coli and Listeria innocua on Fresh-Cut Apple (Granny Smith) Skin. Food and Bioprocess Technology 11(5): 1075-1086.

Son, S. M., Moon, K. D., Lee, C. Y. (2001). Inhibitory effects of various antibrowning agents on apple slices. Food Chemistry 73(1): 23-30.

Sumonsiri, N. (2017). Effect of ascorbic acid and nisin on fresh-cut apples. Carpathian Journal of Food Science \& Technology, 9(4): 71-85.

Sun, W.-J., Zhao, H.-X., Cui, F.-J., Li, Y.H., Yu, S.-L., Zhou, Q., Qian, J.-Y., Dong, Y. (2013). D-isoascorbyl palmitate: lipase-catalyzed synthesis, structural characterization and process optimization using response surface methodology. Chemistry Central Journal 7(1):114.

Swain, T., Hillis, W. E. (1959). The phenolic constituents of Prunus domestica. I.-The quantitative analysis of phenolic constituents. Journal of the Science of Food and Agriculture 10(1): 63-68. 
Tappi, S., Tylewicz, U., Romani, S., Dalla Rosa, M., Rizzi, F., Rocculi, P. (2017). Study on the quality and stability of minimally processed apples impregnated with green tea polyphenols during storage. Innovative Food Science \& Emerging Technologies 39 (Supplement C): 148-155.

Toivonen, P. M. (2004). Postharvest storage procedures and oxidative stress. Hort Science 39(5): 938-942.

Travers, I., Jacquet, A., Brisset, A., Maite, C. (2002). Relationship between the enzymatic determination of starch and the starch iodine index in two varieties of cider apple. Journal of the Science of Food and Agriculture 82(9), 983-989.

Tsouvaltzis, P., Brecht, J. K. (2017). Inhibition of Enzymatic Browning of Fresh-Cut Potato by Immersion in Citric Acid is Not Solely Due to $\mathrm{pH}$ Reduction of the Solution. Journal of Food Processing and Preservation 41(2): e12829.

Watanabe, Y., Fukuda, T., Takahashi, N., Adachi, S. (2014). Optimal Conditions for Lipase-catalyzed Condensation of Erythorbic Acid with Fatty Acids in Organic Solvents. Japan Journal of Food Engineering, 15(3), 143-148.
Vilas-Boas, A. C., Henrique, P. D. C., Lima, L. C. O., Pereira, M. C. D. A. (2015). Conservação de peras minimamente processadas submetidas a tratamentos químicos. Revista Brasileira de Fruticultura 37: 10091019.

Xing, Y., Li, X., Xu, Q., Jiang, Y., Yun, J., Li, W. (2010). Effects of chitosan-based coating and modified atmosphere packaging (MAP) on browning and shelf life of fresh-cut lotus root (Nelumbo nucifera Gaerth). Innovative Food Science \& Emerging Technologies 11(4): 684-689.

Zorzella, C. A., Vendruscolo, J. L., Treptow, R. O. (2003). Qualidade sensorial de "chips" de diferentes genótipos de batatas (Solanum tuberosum L.), cultivos de primavera e outono no Rio Grande do Sul. Revista Brasileira de Agrociência 9(1): 57-63.

\section{Acknowledgements}

The authors acknowledge Embrapa Clima Temperado, Universidade Federal de Pelotas (UFPel), Coordenação de Aperfeiçoamento de Pessoal de Nível Superior (CAPES), and Rasip Agro Pastoril S/A. 